\title{
Response of gas exchange and yield components of field-grown Triticum aestivum L. to elevated ozone in China
}

\author{
Z.-Z. FENG ${ }^{*}$, F.-F. YAO, Z. CHEN, X.-K. WANG*, Q.-W. ZHENG, and Z.-W. FENG \\ State Key Laboratory of Urban and Regional Ecology, Research Center for Eco-Environmental Sciences, \\ Chinese Academy of Sciences, Beijing, 100085, P.R. China
}

\begin{abstract}
To assess photosynthesis and yield components' response of field-grown wheat to increasing ozone $\left(\mathrm{O}_{3}\right)$ concentration (based on diurnal pattern of ambient $\mathrm{O}_{3}$ ) in China, winter wheat (Triticum aestivum L.) cv. Jia 403 was planted in open top chambers and exposed to three different $\mathrm{O}_{3}$ concentrations: $\mathrm{O}_{3}$-free air $(\mathrm{CF})$, ambient air (NF), and $\mathrm{O}_{3}$-free air with additional $\mathrm{O}_{3}\left(\mathrm{CF}+\mathrm{O}_{3}\right)$. Diurnal changes of gas exchange and net photosynthetic rate $\left(P_{\mathrm{N}}\right)$ in response to photosynthetic photon flux density (PPFD) of flag leaves were measured at the filling grain stage, and yield components were investigated at harvest. High $\mathrm{O}_{3}$ concentration altered diurnal course of gas exchange $\left[P_{\mathrm{N}}\right.$, stomatal conductance $\left(g_{\mathrm{s}}\right)$, and intercellular $\mathrm{CO}_{2}$ concentration $\left(C_{\mathrm{i}}\right)$ ] and decreased significantly their values except for $C_{\mathrm{i}}$. Apparent quantum yield (AQY), compensation irradiance (CI), and saturation irradiance (SI) were significantly decreased, suggesting photosynthetic capacity was also altered, characterized as reduced photon-saturated photosynthetic rate $\left(P_{\mathrm{Nmax}}\right)$. The limit of photosynthetic activity was probably dominated by non-stomatal factors in combination with stomatal closure. The significant reduction in yield was observed in $\mathrm{CF}+\mathrm{O}_{3}$ treatment as a result of a marked decrease in the ear length and the number of grains per ear, and a significant increase in the number of infertile florets per ear. Even though similar responses were also observed in plants exposed to ambient $\mathrm{O}_{3}$ concentration, no statistical difference was observed at current ambient $\mathrm{O}_{3}$ concentration in China.
\end{abstract}

Additional key words: apparent quantum yield; diurnal pattern of $\mathrm{O}_{3}$; net photosynthetic rate; irradiance; stomatal conductance; yield components.

\section{Introduction}

Ozone $\left(\mathrm{O}_{3}\right)$ has become one of the most important phytotoxic gaseous pollutants in many parts of the world (Krupa et al. 2001). As predicted by IPCC (2002), ambient $\mathrm{O}_{3}$ concentration at summer would be over $70 \mathrm{~mm}^{3} \mathrm{~m}^{-3}$ in Northern Hemisphere at the end of the century if current levels of anthropogenic activity were maintained. $\mathrm{O}_{3}$ at ambient concentrations in the United States, Europe, and Asia causes a range of effects including reduced photosynthetic activities, altered carbon metabolism, and yield reductions (Soja and Soja 1995, Bosac et al. 1998, Heagle et al. 1998, Meyer et al. 2000, Dizengremel 2001, Fuhrer and Booker 2003, Calatayud et al. 2004, 2006a,b, Skotnica et al. 2005), but the detrimental effects of $\mathrm{O}_{3}$ are dependent on the genetic background, development phase of the plants, $\mathrm{O}_{3}$ doses, and climate (Heath 1994). In China, model simulations and open top chamber (OTC) experiment indicated that $\mathrm{O}_{3}$ pollution is likely to worsen in the coming decades and ground-level $\mathrm{O}_{3}$ is sufficiently high to depress yields of winter wheat and rice (Chameides et al. 1999, Feng et al. 2003).

Ozone enters the plant through open stomata. The phytotoxicity of $\mathrm{O}_{3}$ inside the leaves is due to its high oxidative capacity (redox potential $+2.07 \mathrm{~V}$ ) and the consequential formation of radicals and reactive oxygen species (ROS) in exposed plants, such as hydrogen peroxide $\left(\mathrm{H}_{2} \mathrm{O}_{2}\right)$, superoxide radical anions $\left(\mathrm{O}_{2}^{-}\right)$, and hydroxyl radicals (OH) (Heath 1987, Pell et al. 1997).

Received 7 September 2006, accepted 22 February 2007.

${ }^{*}$ Corresponding author; fax: 86-10-62943822, e-mail: zhzfeng201@163.com; wangxk@rcees.ac.cn

Abbreviations: AQY - apparent quantum yield; $C_{\mathrm{i}}$ - intercellular $\mathrm{CO}_{2}$ concentration; $\mathrm{CF}-\mathrm{O}_{3}$-free air; $\mathrm{CF}+\mathrm{O}_{3}-\mathrm{O}_{3}$-free air with additional $\mathrm{O}_{3}$; CI - compensation irradiance; $g_{\mathrm{s}}$ - stomatal conductance; NF - ambient air; OTCs - open top chambers; $P_{\mathrm{N}}-$ net photosynthetic rate; $P_{\mathrm{Nmax}}$ - photon-saturated photosynthetic rate; $P_{\mathrm{Nmean}}$ - diurnal mean photosynthetic rate; PPFD - photosynthetic photon flux density; SI - saturation irradiance; $\mathrm{T}$ - air temperature.

Acknowledgements: The work is financed by the Ministry of Science and Technology of People's Republic China with 973 Project (No. 2002CB410803) and the National Natural Science Foundation of China (No. 30670387). 
In the chloroplast, these reactions could directly or indirectly impair the light and dark reactions of photosynthesis (Calatayud et al. 2004). Hence, $\mathrm{O}_{3}$ alters photosynthetic activity through various mechanisms. The direct effect of ozone on stomata is a main role in the impairment of photosynthesis (Płażek et al. 2000, Guidi et al. 2001, Calatayud et al. 2004). Moreover, $\mathrm{O}_{3}$ can also inhibit the synthesis of photosynthetic pigments, decreasing the electron transport rate between both photosystems (Calatayud et al. 2004). Clark et al. (2001) indicated that photosynthetic capacity is an ideal physiological activity to monitor when the health and vitality of plants is under scrutiny. Therefore, gas exchange also provides an important source of information about plant growth under $\mathrm{O}_{3}$-enriched environment.

However, most results mentioned above were mostly based on constant concentration fumigation regimes. Meyer et al. (2000) indicated that ozone treatments with

\section{Materials and methods}

Experimental site was located in Shuangqiao Farm $\left(31^{\circ} 53^{\prime} \mathrm{N}, 121^{\circ} 18^{\prime} \mathrm{E}\right)$ at Jiaxing City, Zhejiang Province. The site is about $100 \mathrm{~km}$ far from Shanghai (the biggest city in China). In this region, annual average temperature and precipitation are $15.5^{\circ} \mathrm{C}$ and $1199 \mathrm{~mm}$, respectively. The prevailing cultivation rotations are the rape and rice or wheat and rice. Ozone was the main phytotoxic pollutant present in ambient air reaching a 7-h mean of $46 \mathrm{~mm}^{3} \mathrm{~m}^{-3}$ and a maximum hourly peak of $197 \mathrm{~mm}^{3} \mathrm{~m}^{-3}$ (Zheng et al. 2005).

Plants: Winter wheat (Triticum aestivum L.) seeds (cv. Jia No. 403) were sown in plots $(2 \times 2 \mathrm{~m})$ on 7 November, 2005. In each plot, $60 \mathrm{~kg} \mathrm{~N}, 60 \mathrm{~kg} \mathrm{P}_{2} \mathrm{O}_{5}$, and $60 \mathrm{~kg} \mathrm{~K} \mathrm{~K}_{2} \mathrm{O}$ per ha were fertilized into soil surface when wheat was planted, and followed by an additional $69 \mathrm{~kg} \mathrm{~N}$ per ha at the tillering stage. Plants were maintained in the plots until harvest on 16 May 2006. The plants exposed to $\mathrm{O}_{3}$ fumigation in OTCs started from 13 March 2006, at the jointing stage, and ended on 28 April. The $\mathrm{O}_{3}$ fumigation was carried out from 09:00 to 17:00 per day, and suspended when it was rainy and cloudy. In fact, there were $30 \mathrm{~d}$ for $\mathrm{O}_{3}$ fumigation during the growth season. No irrigation water was applied to the plots from the germination to harvest of wheat.

OTCs were made of steel frame and polythene plastic film, including charcoal filter system, ventilation and gas distribution system, and framework part. Ozone was generated from pure $\mathrm{O}_{2}$ by electric discharge (ozone generator, QHG-1, Yuyao, China) and then mixed with charcoal filtered air to give different ozone concentrations. The mixed gas was transported to every OTC. Concentrations of ozone within the chambers were measured at plant height continuously on a 5 min interval by a ML9810B ozone analyst (Monitor, USA). There comparatively high peak concentration induce more pronounced damage than ozone patterns with moderate peaks under equal dose conditions. Ozone has a typical diurnal profile with peak concentration during the afternoon and low concentrations at night when other pollutants are present. Hence the dynamic fumigation regime according to $\mathrm{O}_{3}$ diurnal changes can really simulate the response process of the plants to increasing ambient $\mathrm{O}_{3}$, and scientifically evaluate the yield loss of crops. The diurnal trend in gas exchange is often recognized as one of the best indications in reflecting the ability of plants to maintain their photosynthetic apparatus to readily respond to environment (Geiger and Servaites 1994). Therefore, the objectives of this study were (1) to assess responses of photosynthesis and yield components of field-grown wheat to elevated $\mathrm{O}_{3}$ level with significant diurnal changes under field condition, and (2) to clarify potential mechanisms of reduced photosynthesis rate.

were three treatments and three replicates of each treatment in this experiment. Three OTCs were ventilated by passing air through activated charcoal filter (CF), three OTCs were ventilated with non-filtered air (NF), and three received additional $\mathrm{O}_{3}\left(\mathrm{CF}+\mathrm{O}_{3}\right)$ based on diurnal change pattern of ambient $\mathrm{O}_{3}$ (Fig. 1). Ozone was added to charcoal-filtered air by means of flow controllers linked to a desktop computer programmed with the individual exposure profiles.

Gas exchange: After $25 \mathrm{~d}$ of exposure to $\mathrm{O}_{3}$, at the stage of grain filling, leaf gas exchange rates, i.e. net photosynthetic rate $\left(P_{\mathrm{N}}\right)$, stomatal conductance $\left(g_{\mathrm{s}}\right)$, and intercellular $\mathrm{CO}_{2}$ concentration $\left(C_{\mathrm{i}}\right)$, photosynthetic photon flux density (PPFD), and leaf temperature were simultaneously recorded every hour from 08:00 to $16: 00$ excluding 15:00 on sunny day with a portable photosynthetic system (CIRAS-1, PP Systems, UK). The flag leaves for experiment were all fully exposed and oriented to normal irradiation during measurements to find gas exchange at the highest possible PPFD. Five replications were done for each treatment at each time.

$P_{\mathrm{N}}$-PPFD response curves were also measured by a portable infra-red gas analyzer CIRAS-1 in the morning when there was no cloud. $\mathrm{CO}_{2}$ and air temperature in the leaf chamber were maintained at $360 \mu \mathrm{mol} \mathrm{mol}^{-1}$ and $25^{\circ} \mathrm{C}$, respectively. PPFD started at $1400 \mu \mathrm{mol} \mathrm{m} \mathrm{m}^{-2} \mathrm{~s}^{-1}$ and decreased stepwise to $40 \mu \mathrm{mol} \mathrm{m} \mathrm{m}^{-2} \mathrm{~s}^{-1}$. Apparent quantum yield (AQY) was calculated from the initial slopes by linear regression using PPFD values below $200 \mu \mathrm{mol} \mathrm{m} \mathrm{m}^{-2} \mathrm{~s}^{-1}$. Compensation irradiance (CI), saturation irradiance $(\mathrm{SI})$, and photon-saturated photosynthetic rate $\left(P_{\mathrm{Nmax}}\right)$ were estimated.

Yield components: The ears length and numbers of grains, spikelets, and infertile florets per ear on each plant 
were recorded. The plants were dried in oven at $80{ }^{\circ} \mathrm{C}$ for $72 \mathrm{~h}$ and dry mass (DM) of grains as well as 1000 -grain mass were also recorded.

Statistical analysis: Variance analysis (ANOVA) was performed on experimental data, and the results were

\section{Results}

Air quality: The data for $\mathrm{O}_{3}$ concentration and environmental conditions during fumigation period are summarized in Table 1. In $\mathrm{CF}+\mathrm{O}_{3}$ treatment, 8-h mean $\mathrm{O}_{3}$ concentration inside the chambers was about 1.0 -fold higher than that of NF. The mean of high-peak in $\mathrm{CF}+\mathrm{O}_{3}$ analyzed by SPSS 10.0 for Windows. The least significant differences (LSD) between the means were estimated at $95 \%$ confidence level. Unless indicated otherwise, significant differences among different treatments are given at $p<0.05$.

treatments during fumigation was approximately 1.3 -fold higher than the high-peak mean in NF conditions. The mean $\mathrm{O}_{3}$ concentration in $\mathrm{CF}$ chambers was lower than $10 \mathrm{~mm}^{3} \mathrm{~m}^{-3}$. The environmental conditions were similar in all treatments during the fumigation.

Table 1. Summary of ozone concentrations and environmental conditions in OTCs during the fumigation of wheat plants. $\left[\mathrm{O}_{3}\right]_{\text {mean }}$, mean $\mathrm{O}_{3}$ concentration $\left[\mathrm{mm}^{3} \mathrm{~m}^{-3}\right] ;\left[\mathrm{O}_{3}\right]_{\min }$ and $\left[\mathrm{O}_{3}\right]_{\max }$, means of the minimum and maximum concentrations during $30 \mathrm{~d}$ in $8 \mathrm{~h}$ a day $\left[\mathrm{mm}^{3} \mathrm{~m}^{-3}\right]$, respectively; $\mathrm{T}_{\text {mean }}$, mean $24-\mathrm{h}$ air temperature $\left[{ }^{\circ} \mathrm{C}\right] ; \mathrm{T}_{\min }$ and $\mathrm{T}_{\max }$, minimum and maximum air temperatures $\left[{ }^{\circ} \mathrm{C}\right]$, and RH [\%], air relative humidity.

\begin{tabular}{lrlccccc}
\hline Treatment & {$\left[\mathrm{O}_{3}\right]_{\text {mean }}$} & {$\left[\mathrm{O}_{3}\right]_{\text {min }}$} & {$\left[\mathrm{O}_{3}\right]_{\max }$} & $\mathrm{T}_{\text {mean }}$ & $\mathrm{T}_{\min }$ & $\mathrm{T}_{\max }$ & $\mathrm{RH}$ \\
\hline $\mathrm{CF}$ & 9.7 & - & - & 13.90 & 8.41 & 20.10 & 66.5 \\
$\mathrm{NF}$ & 52.4 & 34.9 & 68.1 & 13.82 & 8.59 & 19.80 & 65.8 \\
$\mathrm{CF}+\mathrm{O}_{3}$ & 105.0 & 59.0 & 156.0 & 13.72 & 8.48 & 19.50 & 67.2 \\
\hline
\end{tabular}

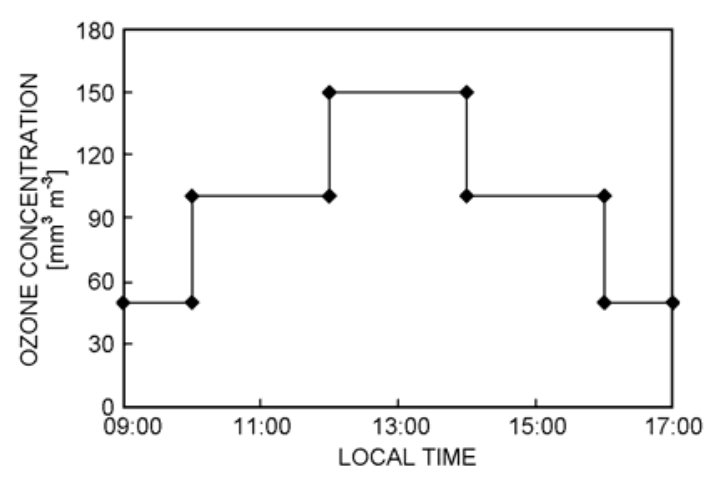

Fig. 1. The profile of $\mathrm{O}_{3}$ concentration in OTCs in the $\mathrm{CF}+\mathrm{O}_{3}$ treatment.

Gas exchanges: In general, $P_{\mathrm{N}}$ was the highest in $\mathrm{CF}$ treatment and the lowest in $\mathrm{CF}+\mathrm{O}_{3}$ treatment (Fig. $2 \mathrm{~B}$ ). The diurnal mean photosynthetic rate $\left(P_{\text {Nmean }}\right)$ in $\mathrm{CF}+\mathrm{O}_{3}$ was significantly lower (about $40 \%$ ) than that in $\mathrm{CF}$ and $\mathrm{NF}$, but the difference between $\mathrm{CF}$ and NF was insignificant (Table 2). $P_{\mathrm{N}}$ displayed a double-peaked diurnal curve at three $\mathrm{O}_{3}$ treatments (Fig. 2B). The midday depressions of wheat occurred at about 12:00 for CF and NF treatments, and at about 11:00 for $\mathrm{CF}+\mathrm{O}_{3}$ treatment. The highest $P_{\mathrm{N}}$ value occurred in 11:00 for CF and NF treatments, whereas its maximum value occurred at 10:00 in $\mathrm{CF}+\mathrm{O}_{3}$ treatment and was $42.4 \%$ lower than that in CF. Ozone altered diurnal course of $g_{\mathrm{s}}$ and decreased significantly its values (Fig. 2C). The midday depression of $g_{\mathrm{s}}$ was observed at 12:00 and 14:00 for $\mathrm{CF}$ and $\mathrm{CF}+\mathrm{O}_{3}$ treatments, respectively. However, the changes in $C_{i}$ were just contrary to those of $P_{\mathrm{N}}$ (Fig. 2D). A significant positive correlation between $P_{\mathrm{N}}$ and $g_{\mathrm{s}}$ and a negative correlation between $g_{\mathrm{s}}$ and $C_{\mathrm{i}}$ were observed (Fig. 3).

As shown in Fig. 4 , all the $P_{\mathrm{N}}$-PPFD response curves reacted rapidly from 0 to $250 \mu \mathrm{mol} \mathrm{m} \mathrm{m}^{-2} \mathrm{~s}^{-1}$, then the curves were gradually at a plateau. $\mathrm{O}_{3}$ fumigation induced a significant decrease in AQY (Table 2), indicating that high $\mathrm{O}_{3}$ concentration led to less efficiency of photon energy use of wheat at the same photon density. In different treatments, CI and SI changed at the range of 27-89 $\mu \mathrm{mol} \mathrm{m} \mathrm{m}^{-2} \mathrm{~s}^{-1}$ and 906-1 $252 \mu \mathrm{mol} \mathrm{m} \mathrm{m}^{-2} \mathrm{~s}^{-1}$, respectively. CI was the highest in $\mathrm{CF}$ and was 1.3 -fold and 1.7-fold higher than that in $\mathrm{NF}$ and $\mathrm{CF}+\mathrm{O}_{3}$, respectively. In $\mathrm{CF}+\mathrm{O}_{3}$ treatments, $P_{\mathrm{Nmax}}$ and SI were 27.6 and $40.3 \%$ lower than those in $\mathrm{CF}$, respectively (Table 2). There was no significant difference between $\mathrm{CF}$ and NF except for CI and SI.

Yield components: In comparison with $\mathrm{CF}, \mathrm{O}_{3}$ caused a significant reduction $(28.6 \%)$ in the number of grains per ear as a result of an $\mathrm{O}_{3}$-induced reduction in the length per ear $(9.5 \%)$ and an increase in the number of infertile florets per ear $(128 \%)$, although no significant differences were observed in the number of spikelets per ear (Table 3). Moreover, 1000 -grain mass and grain yield of wheat exposed to $\mathrm{CF}+\mathrm{O}_{3}$ treatment were reduced by 20.6 and $36.0 \%$, respectively, compared with $\mathrm{CF}$ treatment. Even though ambient $\mathrm{O}_{3}$ concentration also decreased the yields and 1000 -grain mass, no statistical difference was observed between CF and NF. 


\section{Discussion}

Most studies indicated that $\mathrm{O}_{3}$ significantly induced a decrease in $P_{\mathrm{N}}$ and crop yields (Bosac et al. 1998, Heagle et al. 1998, Meyer et al. 2000, Feng et al. 2003, 2006, Calatayud et al. 2004). In our study, $\mathrm{O}_{3}$ affected the photosynthetic capacity in wheat plants, including changes in diurnal pattern of gas exchanges and $P_{\mathrm{N}}$-PPFD response parameters, and thus a decrease in yield components was observed.

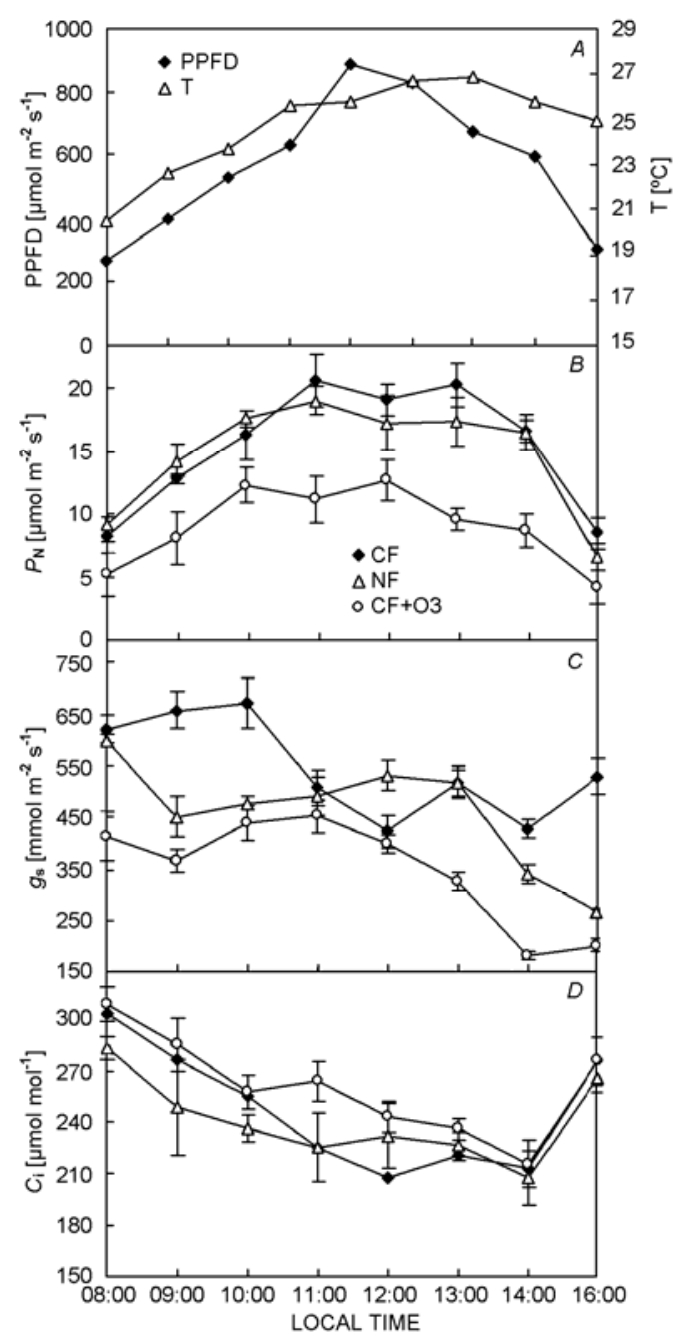

Fig. 2. Diurnal trends of photosynthetic photon flux density (PPFD) and air temperature $(\mathrm{T})(A)$, net photosynthetic rate $\left(P_{\mathrm{N}}\right)$, stomatal conductance $\left(g_{\mathrm{s}}\right)$, and intercellular $\mathrm{CO}_{2}$ concentration $\left(C_{\mathrm{i}}\right)$ of wheat flag leaf exposed to different $\mathrm{O}_{3}$ concentrations $(B-D)$. SEs are shown $(n=5)$.

Photosynthesis is the primary physiological process by which plants respond to changes in environmental air conditions. Most studies showed stomata closure under stress, and consequent decrease in $P_{\mathrm{N}}$ (Farquhar and Sharkey 1982, Calatayud et al. 2004). However, environmental stress may usually act on chloroplast directly with a decrease in $P_{\mathrm{N}}$, thus becoming non-stomata factors in restricting $P_{\mathrm{N}}$ (Heath 1987, Mackerness 2000, Zheng et al. 2000). Therefore, the factors causing a decrease in $P_{\mathrm{N}}$ can be grouped into stomatal and non-stomatal ones (Shangguan et al. 1999). The closure of stomata results in the shortage of $\mathrm{CO}_{2}$ (Boyer 1976). Non-stomatal factors include: (1) the increase in diffusive resistance to $\mathrm{CO}_{2}$ in mesophyll; (2) the decrease in activities of photosystem 2, photophosphorylation, and ribulose-1,5-bisphosphate carboxylase; (3) the decrease in chlorophyll content and inhibition of electron transport (Wise et al. 1992, Heath 1994, Shangguan et al. 1999, Mackerness 2000, Hassan 2006), etc. If stomatal factors are the main ones, $P_{\mathrm{N}}$ and $g_{\mathrm{s}}$ decrease owing to the decline in $C_{\mathrm{i}}$. Otherwise, the decrease in $P_{\mathrm{N}}$ is dominated by nonstomatal factors. We found that the close positive correlation between $P_{\mathrm{N}}$ and $g_{\mathrm{s}}$ (Fig. $3 A$ ) indicated that the midday depression of $P_{\mathrm{N}}$ in wheat might be due to stomatal closure. But the increase in $g_{\mathrm{s}}$ was always accompanied by a decrease in $C_{\mathrm{i}}$ (Fig. $3 B$ ), suggesting the midday depression of $P_{\mathrm{N}}$ was not caused primarily by the lower $g_{\mathrm{s}}$, but rather by non-stomatal factors. The results may be related with designed ozone concentration scenario. In this scenario, comparatively high peak of $\mathrm{O}_{3}$ concentration did not accompany the highest PPFD, thus $\mathrm{O}_{3}$ went into mesophyll cells through stomata easily. Once $\mathrm{O}_{3}$ entered into mesophyll, it severely damaged the structure and function of photosynthetic organ (Lütz et al. 2000), and was accompanied by a series of physiological and biochemical characters altering in plant, such as an increase of membrane permeability, protein decomposition, and lipid peroxidation (Jin et al. 2000, Lütz et al. 2000, Płażek et al. 2000, Calatayud et al. 2004). Therefore, a significant decrease in $P_{\mathrm{N}}$ was found in additional $\mathrm{O}_{3}$ treatment $\left(\mathrm{CF}+\mathrm{O}_{3}\right)$, which was also observed by Meyer et al. (2000) under two different $\mathrm{O}_{3}$ concentration peak regimes.

The asymptotic part of the $P_{\mathrm{N}}-\mathrm{PPFD}$ curve (PPFD> $400 \mu \mathrm{mol} \mathrm{m} \mathrm{m}^{-2} \mathrm{~s}^{-1}$ ) is predominantly limited by ribulose1,5-bisphosphate carboxylase/oxygenase (RuBPCO; e.g. Feng et al. 2006), hypothesizing a decrease of RuBPCO amount and activity among $\mathrm{O}_{3}$ treatments (Fig. 4). Also, Eckardt and Pell (1995) demonstrated a decrease of RuBPCO carboxylase efficiency in potato leaves in response to increased $\mathrm{O}_{3}$. Values of AQY demonstrated a stronger damage of assimilation apparatus by excess photon absorption and photochemical utilization in plants exposed to $\mathrm{CF}+\mathrm{O}_{3}$ treatment (decrease by $28.6 \%$ relative to $\mathrm{CF}$ ). SI and $\mathrm{CI}$ are the important traits for photon energy utilization capability. In comparison with $\mathrm{CF}, \mathrm{O}_{3}$ caused a significant decrease in SI (about $40 \%$ ) and CI (70\%), which indicted that lower effective irradiance was utilized by $\mathrm{O}_{3}$-treated plants (Table 2). Even though saturated photon irradiance was applied, the plants in $\mathrm{CF}+\mathrm{O}_{3}$ treatment had a lower $P_{\text {Nmax }}(p<0.05)$, suggesting photosynthetic capacity of wheat exposed to additional 
Table 2. Comparison of mean net photosynthetic rate $\left(P_{\text {Nmean }}\right)$, photosynthetic characteristics $\left(P_{\text {Nmax }}\right.$, photon-saturated photosynthetic rate; AQY, apparent quantum yield; SI, saturation irradiance; CI, compensation irradiance) in wheat leaves under three $\mathrm{O}_{3}$ treatments. Means \pm SE of four replicates. Values in columns followed by the different letters are statistically different at $p<0.05$ (LSD-test).

\begin{tabular}{llllll}
\hline Treatment & $\begin{array}{l}P_{\text {Nmean }} \\
{\left[\mu \mathrm{mol} \mathrm{m} \mathrm{s}^{-1}\right]}\end{array}$ & $\begin{array}{l}P_{\text {Nmax }} \\
{\left[\mu \mathrm{mol} \mathrm{m} \mathrm{s}^{-1}\right]}\end{array}$ & AQY & $\begin{array}{l}\text { SI } \\
{\left[\mu \mathrm{mol} \mathrm{m}^{-2} \mathrm{~s}^{-1}\right]}\end{array}$ & $\begin{array}{l}\text { CI } \\
{\left[\mu \mathrm{mol} \mathrm{m}^{-2} \mathrm{~s}^{-1}\right]}\end{array}$ \\
\hline $\mathrm{CF}$ & $15.10 \pm 0.53 \mathrm{a}$ & $23.10 \pm 2.51 \mathrm{a}$ & $0.063 \pm 0.001 \mathrm{a}$ & $1252 \pm 38 \mathrm{a}$ & $89.44 \pm 4.85 \mathrm{a}$ \\
$\mathrm{NF}$ & $14.90 \pm 0.60 \mathrm{a}$ & $19.10 \pm 2.39 \mathrm{ab}$ & $0.058 \pm 0.005 \mathrm{a}$ & $1095 \pm 47 \mathrm{~b}$ & $30.71 \pm 5.09 \mathrm{~b}$ \\
$\mathrm{CF}+\mathrm{O}_{3}$ & $8.92 \pm 0.68 \mathrm{~b}$ & $13.80 \pm 1.34 \mathrm{~b}$ & $0.045 \pm 0.003 \mathrm{~b}$ & $906 \pm 42 \mathrm{c}$ & $27.12 \pm 4.56 \mathrm{~b}$ \\
\hline
\end{tabular}

Table 3. Yield components of wheat exposed to three $\mathrm{O}_{3}$ treatments. Means $\pm \mathrm{SE}$ of three replicates. Values in columns followed by different letters are statistically different at $p<0.05$ (LSD-test).

\begin{tabular}{lrlllll}
\hline & Ear length & $\begin{array}{l}\text { Spikelets } \\
\text { per ear }\end{array}$ & $\begin{array}{l}\text { Grains } \\
\text { per ear }\end{array}$ & $\begin{array}{l}\text { Infertile florets } \\
\text { per ear }\end{array}$ & $\begin{array}{l}\text { 1 000-grain } \\
\text { dry mass [g] }\end{array}$ & $\begin{array}{l}\text { Grain yield } \\
\text { [g plant }^{-1} \text { ] }\end{array}$ \\
\hline $\mathrm{CF}$ & $11.00 \pm 0.36 \mathrm{a}$ & $17.90 \pm 0.74 \mathrm{a}$ & $46.90 \pm 3.93 \mathrm{a}$ & $2.50 \pm 0.33 \mathrm{a}$ & $37.40 \pm 1.37 \mathrm{a}$ & $1.75 \pm 1.01 \mathrm{a}$ \\
$\mathrm{NF}$ & $11.00 \pm 0.53 \mathrm{a}$ & $17.70 \pm 0.95 \mathrm{a}$ & $46.20 \pm 4.25 \mathrm{a}$ & $2.60 \pm 0.22 \mathrm{a}$ & $32.00 \pm 0.78 \mathrm{ab}$ & $1.31 \pm 0.11 \mathrm{ab}$ \\
$\mathrm{CF}+100$ & $9.95 \pm 0.47 \mathrm{~b}$ & $16.40 \pm 1.06 \mathrm{a}$ & $33.50 \pm 3.29 \mathrm{~b}$ & $5.70 \pm 1.04 \mathrm{~b}$ & $29.70 \pm 1.20 \mathrm{~b}$ & $1.12 \pm 0.11 \mathrm{~b}$ \\
\hline
\end{tabular}
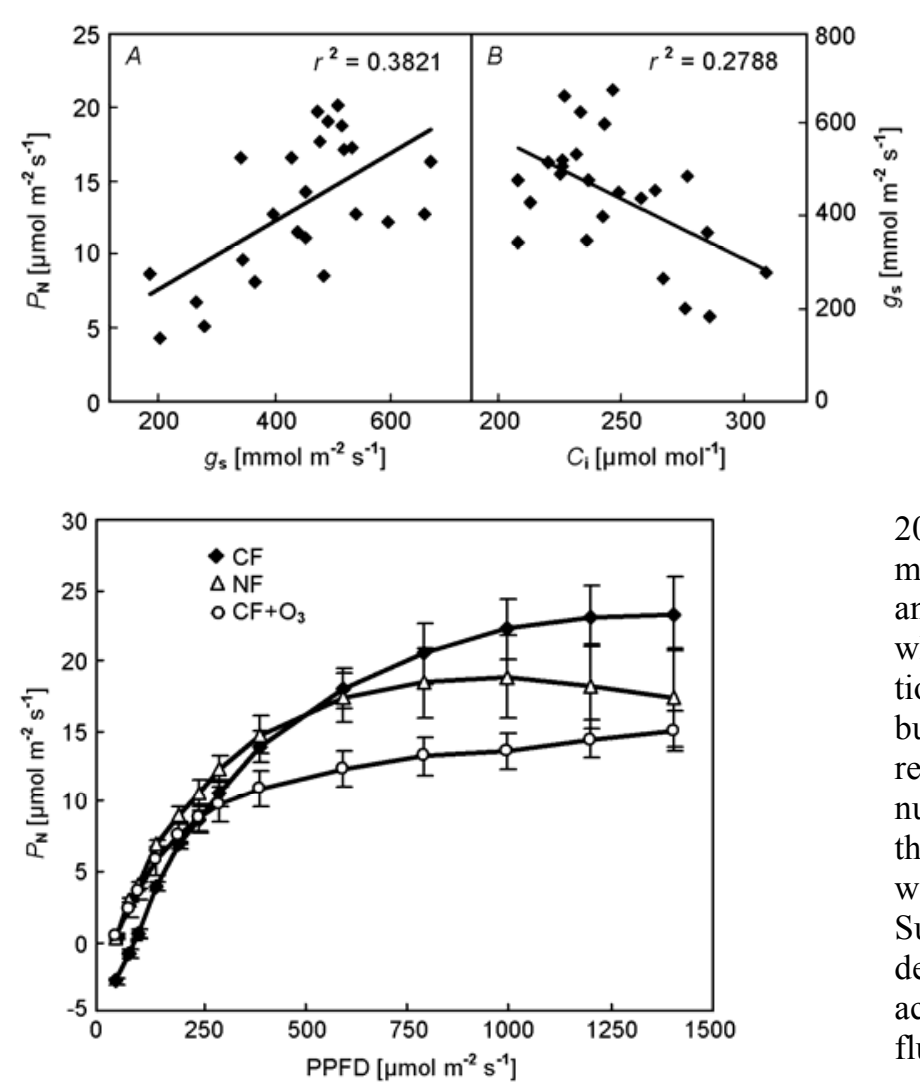

Fig. 4. Photosynthetic photon flux density (PPFD) response curves of net photosynthetic rate $\left(P_{\mathrm{N}}\right)$ of field-grown wheat under different $\mathrm{O}_{3}$ treatments. $P_{\mathrm{N}}$ was measured at $\mathrm{CO}_{2}$ concentration of $360 \mu \mathrm{mol} \mathrm{mol}{ }^{-1}$, temperature of $25{ }^{\circ} \mathrm{C}$, and PPFD of $0-1400 \mu \mathrm{mol} \mathrm{m}^{-2} \mathrm{~s}^{-1}$. SEs are shown $(n=4)$.

$\mathrm{O}_{3}$ had been seriously depressed.

Literature on wheat productivity in response to enhanced $\mathrm{O}_{3}$ is contradictory. Most studies underlined a reduction in yields (Ojanpera et al. 1998, Feng et al.
Fig. 3. Relationship between $(A)$ net photosynthetic rate $\left(P_{\mathrm{N}}\right)$ and stomatal conductance $\left(g_{\mathrm{s}}\right)$ or $(B)$ between $g_{\mathrm{s}}$ and intercellular $\mathrm{CO}_{2}$ concentration $\left(C_{\mathrm{i}}\right)$ of wheat flag exposed to different $\mathrm{O}_{3}$ concentrations $(n=24)$.

2003), whereas Finnan et al. (1996) reported higher biomass and yield of wheat exposed to low $\mathrm{O}_{3}$ concentration and no significant changes were also observed in spring wheat (Mulholland et al. 1997). In our paper, the reduction in yield was observed in $\mathrm{CF}+\mathrm{O}_{3}$ treatment $(p<0.05)$, but not in NF in comparison with $\mathrm{CF}$, which were the results of (1) a marked decrease in the ear length and the number of grains per ear, and (2) a significant increase in the number of infertile florets per ear. Similar results were also observed in spring wheat (Finnan et al. 1996). Such reductions in grain yield have been attributed to decreased $P_{\mathrm{N}}$ (Meyer et al. 2000, Feng et al. 2006) and accelerated flag leaf senescence or alteration in $\mathrm{Chl}$ fluorescence (Calatayud et al. 2004).

From the above results, ozone episodes (diurnal pattern) as applied in this experiment are capable of reducing significantly the physiological vitality and yields of wheat. Hence setting of thresholds for atmospheric ozone should consider peak concentrations more effectively. For more realistic effects of $\mathrm{O}_{3}$ on crops, further investigations are important concerning the influence of environmental factors on the actual absorbed ozone dose of plants $\left(\mathrm{O}_{3}\right.$ flux $)$. 


\section{References}

Bosac, A., Black, V.J., Roberts, J.A., Black, C.R.: Impact of ozone on seed yield and quality and seedling vigour in oilseed rape (Brassica napus L.). - J. Plant Physiol. 153: 127-134, 1998.

Boyer, J.S.: Water deficits and photosynthesis. - In: Kozlowski, T.T. (ed.): Water Deficits and Plant Growth. Vol. IV. Pp. 153190. Academic Press, New York - San Francisco - London 1976.

Calatayud, A., Iglesias, D.J., Talón, M., Barreno, E.: Response of spinach leaves (Spinacia oleracea L.) to ozone measured by gas exchange, chlorophyll $a$ fluorescence, antioxidant systems, and lipid peroxidation. - Photosynthetica 42: 23-29, 2004.

Calatayud, A., Iglesias, D.J., Talón, M., Barreno, E.: Effects of long-term ozone exposure on citrus: Chlorophyll $a$ fluorescence and gas exchange. - Photosynthetica 44: 548-554, $2006 \mathrm{a}$.

Calatayud, A., Pomares, F., Barreno, E.: Interactions between nitrogen fertilization and ozone in watermelon cultivar Reina de Corazones in open-top chambers. Effects on chlorophyll $a$ fluorescence, lipid peroxidation, and yield. - Photosynthetica 44: 93-101, 2006b.

Chameides, W.L., Li, X., Tang, X.., Zhou, X., Luo, C., Kiang, C., John, S., Saylor, R.D., Liu, S., Lam, K.S., Wang, T., Giorgi, F.: Is ozone pollution affecting crop yield in China? Geophys. Res. Lett. 26: 867-870, 1999.

Clark, A.J., Landolt, W., Bucher, J.B., Strasser, R.J.: Beech (Fagus sylvatica) response to ozone exposure assessed with a chlorophyll $a$ fluorescence performance index. - Environ. Pollut. 109: 501-507, 2000.

Dizengremel, P.: Effects of ozone on the carbon metabolism of forest trees. - Plant Physiol. Biochem. 39: 729-742, 2001.

Eckardt, N.A., Pell, E.J.: Oxidative modification of Rubisco from potato foliage in response to ozone. - Plant Physiol. Biochem. 33: 273-282, 1995.

Farquhar, G.D., Sharkey, T.D.: Stomatal conductance and photosynthesis. - Annu. Rev. Plant Physiol. 33: 317-345, 1982.

Feng, Z.W., Jin, M.H., Zhang, F.Z.: Effects of ground-level ozone $\left(\mathrm{O}_{3}\right)$ pollution on the yields of rice and winter wheat in the Yangtze River Delta. - J. environ. Sci. 15: 360-362, 2003.

Feng, Z.Z., Wang, X.K., Zheng, Q.W., Feng, Z.W., Xie, J.Q., Chen, Z.: Response of gas exchange of rape to ozone concentration and exposure regime. - Acta ecol. sin. 26: 823-829, 2006.

Finnan, J.M., Jones, M.B., Burke, J.I.: A time-concentration study on the effects of ozone on spring wheat (Triticum aestivum L.). 1. Effects on yield. - Agr. Ecosyst. Environ. 57: 159-167, 1996.

Fuhrer, J., Booker, F.: Ecological issues related to ozone: Agricultural issues. - Environ. Int. 29: 141-154, 2003.

Geiger, D.R., Servaites, J.C.: Diurnal regulation of photosynthetic carbon metabolism in $\mathrm{C}_{3}$ plants. - Annu. Rev. Plant Physiol. Plant mol. Biol. 45: 235-256, 1994.

Guidi, L., Nali, C., Lorenzini, G., Filippi, F., Soldatini, G.F.: Effect of chronic ozone fumigation on the photosynthetic process of poplar clones showing different sensitivity. Environ. Pollut. 113: 245-254, 2001.

Hassan, I.A.: Effects of water stress and high temperature on gas exchange and chlorophyll fluorescence in Triticum aestivum L. - Photosynthetica 44: 312-315, 2006.

Heagle, A.S., Miller, J.E., Pursley, W.A.: Influence of ozone stress on soybean response to carbon dioxide enrichment. III.
Yield and seed quality. - Crop Sci. 38: 128-134, 1998.

Heath, R.L.: The biochemistry of ozone attack on plasma membrane of plant cells. - Rec. Adv. Phytochem. 21: 29-51, 1987.

Heath, R.L.: Possible mechanisms for the inhibition of photosynthesis by ozone. - Photosynth. Res. 39: 439-451, 1994.

IPCC: Climate Changes 2001. - Cambridge University Press, Cambridge - New York 2002.

Jin, M.H., Feng, Z.W., Zhang, F.Z.: [Effects of ozone on membrane lipid peroxidation and antioxidant system of rice leaves.] - Environ. Sci. 21: 1-5, 2000. [In Chin.]

Krupa, S., McGrath, M.T., Andersen, C.P., Booker, F., Burkey, K., Chappelka, A., Chevone, B., Pell, E., Zilinskas, B.: Ambient ozone and plant health. - Plant Disease 85: 4-12, 2001.

Lütz, C., Anegg, S., Gerant, D., Alaoui-Sossé, B., Gérard, J., Dizengremel, P.: Beech trees exposed to high $\mathrm{CO}_{2}$ and to simulated summer ozone levels: Effects on photosynthesis, chloroplast components and leaf enzyme activity. - Physiol. Plant. 109: 252-259, 2000.

Mackerness, S.A.H.: Plant responses to ultraviolet-B (UV-B: 280-320 nm) stress: what are the key regulators? - Plant Growth Regul. 32: 27-39, 2000.

Meyer, U., Kollner, B., Willenbrink, J., Krause, G.H.M.: Effects of different ozone exposure regimes on photosynthesis, assimilates and thousand grain weight in spring wheat. - Agr. Ecosyst. Environ. 78: 49-55, 2000.

Mulholland, B.J., Craigon, J., Black, C.R., Colls, J.J., Atherton, J., Landon, G.: Effects of elevated carbon dioxide and ozone on the growth and yield of spring wheat (Triticum aestivum L.). - J. exp. Bot. 48: 113-122, 1997.

Ojanpera, K., Patsikka, E., Ylaranta, T.: Effects of low ozone exposure of spring wheat on net $\mathrm{CO}_{2}$ uptake, Rubisco, leaf senescence and grain filling. - New Phytol. 138: 451-460, 1998.

Pell, E.J., Schlagnhaufer, C.D., Arteca, R.N.: Ozone-induced oxidative stress: mechanisms of action and reaction. Physiol. Plant. 100: 264-273, 1997.

Płażek, A., Rapacz, M., Skoczowski, A.: Effects of ozone fumigation on photosynthesis and membrane permeability in leaves of spring barley, meadow fescue, and winter rape. Photosynthetica 38: 409-413, 2000.

Shangguan, Z., Shao, M., Dyckmans, J.: Interaction of osmotic adjustment and photosynthesis in winter wheat under soil drought. - J. Plant Physiol. 154: 753-758, 1999.

Skotnica, J., Gilbert, M., Weingart, I., Wilhelm, C.: The mechanism of the ozone-induced changes in thermoluminescence glow curves of barley leaves. - Photosynthetica 43: 425-434, 2005.

Soja, G., Soja, A.-M.: Ozone effects on dry matter partitioning and chlorophyll fluorescence during plant development of wheat. - Water Air Soil Pollut. 85: 1461-1466, 1995.

Wise, R.R., Ortiz-Lopez, A., Ort, D.R.: Spatial distribution of photosynthesis during drought in field-grown and acclimated and nonacclimated growth chamber-grown cotton. - Plant Physiol. 100: 26-32, 1992.

Zheng, Q.W., Wang, X.K., Feng, Z.Z., Song, W.Z., Feng, Z.W.: [In situ effects of ozone on chlorophyll content and lipid peroxidation in the leaves of winter wheat.] - Acta bot. boreal.occident. sin. 25: 2240-2244, 2005. [In Chin.]

Zheng, Y., Lyons, T., Ollerenshaw, J.H., Barnes, J.D.: Ascorbate in the leaf apoplast is a factor mediating ozone resistance in Plantago major. - Plant Physiol. Biochem. 38: 403-411, 2000. 